\title{
Somatotropin in the treatment of growth hormone deficiency and Turner syndrome in pediatric patients: a review
}

This article was published in the following Dove Press journal:

Clinical Pharmacology:Advances and Applications

I June 2010

Number of times this article has been viewed

\author{
Christina Southern Reh' \\ Mitchell E Geffner ${ }^{1,2}$ \\ 'Childrens Hospital Los Angeles, \\ Keck School of Medicine of USC, \\ Division of Endocrinology, Diabetes, \\ and Metabolism, Los Angeles, CA, \\ USA; ${ }^{2}$ Saban Research Institute, \\ Childrens Hospital Los Angeles, \\ Los Angeles, CA, USA
}

\begin{abstract}
Growth hormone (GH), also known as somatotropin, is a peptide hormone that is synthesized and secreted by the somatotrophs of the anterior pituitary gland. The main action of GH is to stimulate linear growth in children; however, it also fosters a healthy body composition by increasing muscle and reducing fat mass, maintains normal blood glucose levels, and promotes a favorable lipid profile. This article provides an overview of the normal pathophysiology of GH production and action. We discuss the history of GH therapy and the development of the current formulation of recombinant human GH given as daily subcutaneous injections. This paper reviews two of the longest standing FDA-approved indications for GH treatment, GH deficiency and Turner syndrome. We will highlight the pathogenesis of these disorders, including presentations, presumed mechanism(s) for the associated short stature, and diagnostic criteria, with a review of stimulation test benefits and pitfalls. This review also includes current recommendations for GH therapy to help maximize final height in these children, as well as data demonstrating the efficacy and safety of GH treatment in these populations.
\end{abstract}

Keywords: somatotropin, growth hormone, Turner syndrome, pediatric patients

\section{Introduction}

\section{Growth hormone pathophysiology}

Growth hormone $(\mathrm{GH})$, also known as somatotropin, is a peptide hormone that is synthesized and secreted by the somatotrophs of the anterior pituitary gland. ${ }^{1}$ The main effect of $\mathrm{GH}$ is to promote linear growth in children. Its secretion is pulsatile and primarily controlled by GH-releasing hormone (GHRH) (stimulatory), by somatostatin (inhibitory), and, to a lesser degree, by ghrelin (stimulatory). ${ }^{2}$ A complex feedback system involving insulin-like growth factor-1 (IGF-1), leptin, ghrelin, free fatty acids, and the central nervous system regulates GH secretion. ${ }^{3,4}$ When released, GH binds to its receptor in the liver and cartilage, leading to production of IGF-1, which through endocrine and paracrine/autocrine mechanisms, then stimulates linear bone growth. ${ }^{5}$ $\mathrm{GH}$ acts at the epiphysis (growth plate) to increase linear growth by promoting differentiation of prechondrocytes and expansion of osteoblasts. ${ }^{6,7}$ Both GH and IGF-1 are needed to stimulate normal linear growth; however, the exact cellular targets for the direct effects of GH remain ill-defined in complex tissues such as the growth plate. The contribution of the direct and indirect actions of $\mathrm{GH}$ is controversial. ${ }^{8}$ It is known that, when $\mathrm{GH}$ binds to its receptor, it causes dimerization of the receptor, which leads to interaction of the receptor with janus kinase 2 (JAK2) and subsequent tyrosine phosphorylation of JAK2 and the GH receptor itself, followed by changes in the phosphorylation of the signal transducer activator of transcription (STAT) pathway
Correspondence: Christina Southern Reh Fellow, Division of Endocrinology and Metabolism, Childrens Hospital Los Angeles, 4650 Sunset Blvd, Mailstop \#6I, Los Angeles, CA 90027, USA

$\mathrm{Tel}+\mathrm{I} 323-36 \mid-8816$

$\mathrm{Fax}+\mid$ 323-36|-8152

Email csouthern@chla.usc.edu 
which then stimulates target gene transcription. In the liver, $\mathrm{GH}$ receptor activation leads to an increased production of IGF binding protein-3 (IGFBP-3) and acid-labile subunit (ALS) which bind IGF-1 in a ternary complex thereby increasing its half-life ${ }^{9}$ (Figure 1).

\section{$\mathrm{GH}$ actions}

The endogenous and exogenous effects of $\mathrm{GH}$ involve four main areas. First, GH stimulates linear bone growth as discussed above. Second, GH increases bone mass. Third, $\mathrm{GH}$ acts on adipose tissue to increase lipolysis, inhibit lipoprotein lipase, stimulate hormone-sensitive lipase, decrease glucose transport, and decrease lipogenesis. Fourth, $\mathrm{GH}$ acts on muscle to increase transport of amino acids and may affect muscle fiber distribution. ${ }^{10}$ Thus, in patients with GH deficiency (GHD), GH therapy not only increases linear growth velocity, but also promotes maintenance of healthy body composition (increased muscle and reduced fat mass), normal blood glucose levels, and a favorable lipid profile.

\section{Pharmacology of GH}

\section{GH medication development}

Multiple advances in the treatment of GHD have been made in the more than 50 years since treatment began in $1958 .{ }^{11}$
Initially, human pituitary GH, derived from pituitary glands of recently deceased humans, was used only for severely GH-deficient children. Limited supply of the hormone and transmission of Creuzfeldt-Jacob Disease in some patients after treatment led to discontinued use of human cadaveric GH in 1985. ${ }^{12}$ The structure of GH was determined in 1972 and this led to research and development of synthetic GH. In 1979, Goeddel et al expressed the gene for human GH in Escherichia coli allowing the bacteria to produce human GH in large quantities. ${ }^{13}$ In 1985 , Genentech became the first company to make recombinant human $\mathrm{GH}$ (rhGH), also known as somatotropin. ${ }^{14}$

$\mathrm{GH}$ has two known isoforms, weighing $22 \mathrm{kD}$ and $20 \mathrm{kD}$; their structures are shown below (Figure 2). The first available rhGH, protropin, was a polypeptide hormone produced by inclusion body recombinant DNA technology. Protropin had 192 amino acids and a molecular weight of $22 \mathrm{kDa}$. This molecule contained the identical sequence of 191 amino acids found in native pituitary hormone with the addition of a methionine (met-GH) on the N-terminus, initially required to facilitate the biosynthetic process using E. coli. Use of met-GH was associated with the development of antibodies, although typically not of a growth-neutralizing variety. ${ }^{15}$ All current forms of rhGH used in practice today

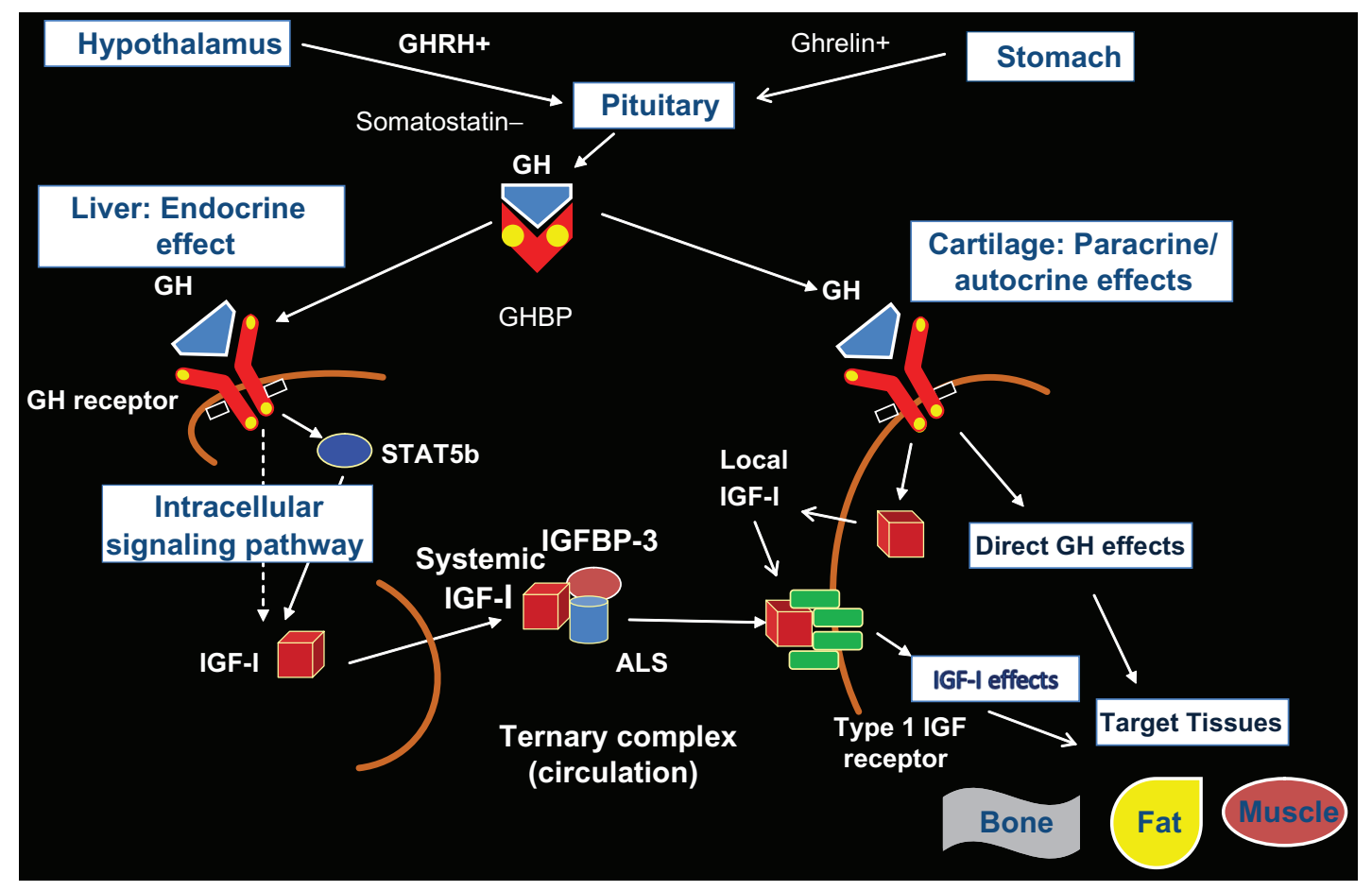

Figure I Growth hormone-IGF-I axis.

Abbreviations: GHRH, growth hormone releasing hormone; GH, growth hormone; GHBP, growth hormone binding protein; IGF-I, insulin-like growth factor-I; IGFBP-3, insulin-like growth factor binding protein-3; ALS, acid-labile subunit; STAT5b, signal transducer activator of transcription pathway 5 b. 


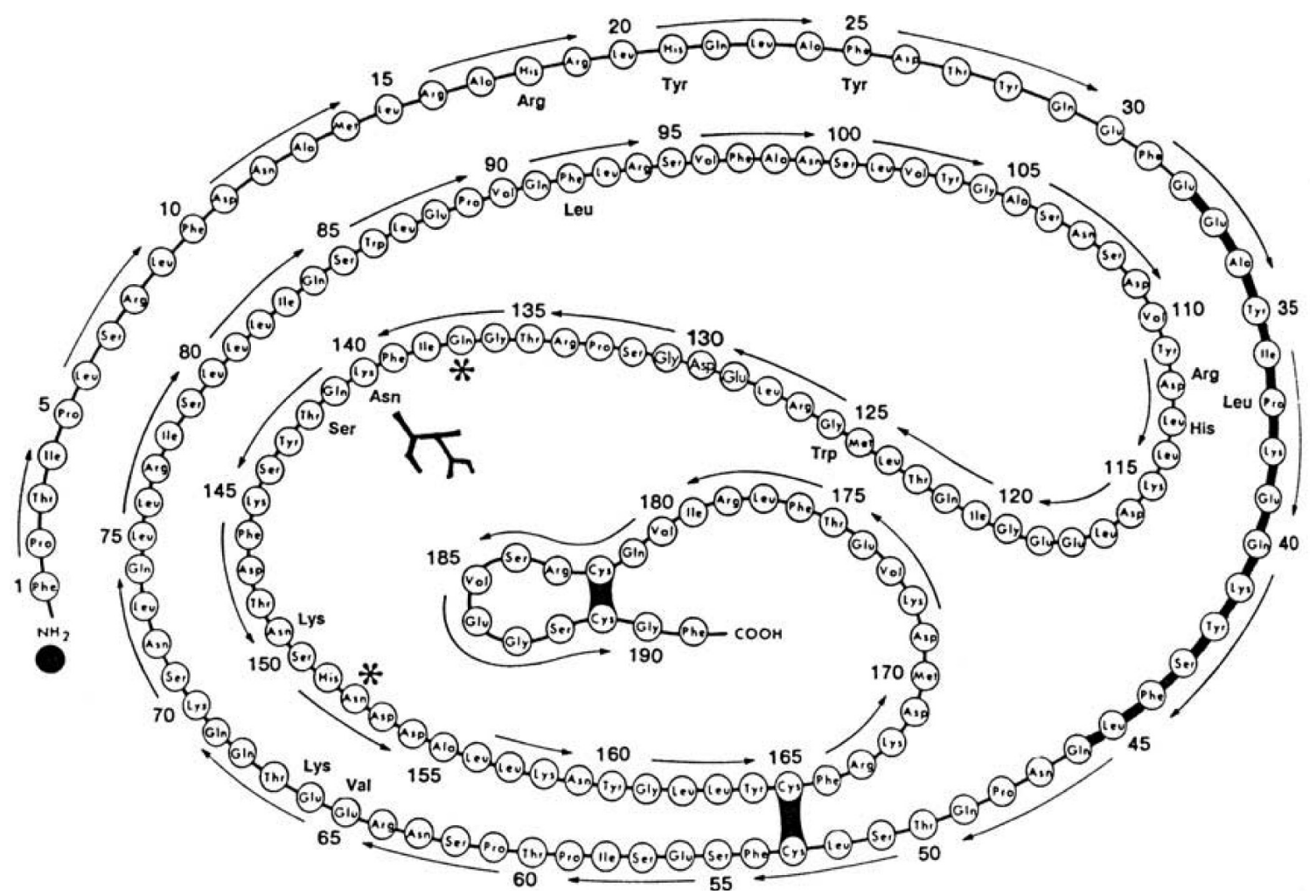

Figure 2 Primary structure of human growth hormone $(\mathrm{GH})$ and its isoforms. The main chain represents $22 \mathrm{~K}-\mathrm{GH}$ (GH-N). The sequence indicated by the bold line from residue $32-46$ is deleted in $20 \mathrm{~K}-\mathrm{GH}$. The black dot at the amino terminus denotes the acyl group in $\mathrm{N}$-acylated $\mathrm{GH}$. The two asterisks denote the deamidated residues in desamido-GH forms. The amino acid designations next to the main chain denote the residues that are changed in $\mathrm{GH}-\mathrm{V}$ (placental GH). The tree structure at residue I40 indicates the glycosylation site in glycosylated GH-V. Reprinted with permission from Baumann GP. Growth hormone isoforms. Growth Horm IGF Res. 2009; I9(4):333-340. ${ }^{2}$ Copyright (c) 2009 Elsevier.

have the identical 191 amino-acid sequence found in native pituitary hormone. ${ }^{16}$ There are no clinically relevant antibody reactions to current rhGH as it mimics the human GH structure.

\section{$\mathrm{GH}$ indications}

There are 11 US Food and Drug Administration (FDA)approved conditions to date that have been shown to benefit from rhGH therapy (Table 1). The dose used varies by age, physiology, indication, response to treatment, and individual practice preferences of the prescribing physician. In addition, the range of doses, at least for pediatric indications, also stems from results of clinical trials in which initial dosage choices were based on the presence of GH deficiency (lower doses) or (presumed) GH resistance (higher doses). Furthermore, dose selection is also sometimes driven by regulations set forth by third-party payers. Review of GH products available in the US reveals that no single brand is approved for all indications. ${ }^{16}$ However, since the active medication, somatotropin, is the same in each product, many physicians feel comfortable using any approved product for any appropriate indication. Similarly, in other parts of the world, GH products are often used interchangeably. The drug approval process in Europe via the European Medicines Evaluation Agency (EMEA) is likely to approve new preparations of rhGH for indications approved for "biosimilar" products. It is suggested by Ranke et al that this type of approval, if granted, should be used with caution as safety and efficacy may be different between medication brands even though the active medication is

Table I Food and Drug Administration (FDA) indications for growth hormone $(\mathrm{GH})$ treatment $^{16}$

\begin{tabular}{ll}
\hline $\begin{array}{l}\text { Year of initial } \\
\text { FDA approval }\end{array}$ & Indications for GH treatment \\
\hline 1985 & Pediatric growth hormone deficiency \\
1993 & $\begin{array}{l}\text { Growth failure secondary to chronic renal } \\
\text { failure up to the time of renal transplantation }\end{array}$ \\
1996 & Adult growth hormone deficiency \\
1996 & HIV wasting in adults \\
1996 & Turner syndrome \\
2000 & Prader-Willi syndrome \\
2001 & Small for gestational age \\
2003 & Idiopathic short stature \\
2003 & Short bowel syndrome \\
2006 & SHOX gene deficiency \\
2007 & Noonan syndrome \\
\hline
\end{tabular}


similar. ${ }^{17}$ Ultimately, the informed physician and often the insurance company will influence the choice of the GH product selected for each patient.

This review will provide an overview of two of the longest-standing indications for GH treatment, GHD and Turner syndrome (TS), in which we will highlight the pathogenesis of these disorders, including presentation, presumed mechanism(s) for the associated short stature, diagnostic criteria, and current recommendations for $\mathrm{GH}$ treatment, including the efficacy and safety of GH use.

\section{Growth hormone deficiency Background - presentation, causes, and diagnosis}

GHD normally presents with short stature, poor height velocity, relative weight preservation, and delayed bone age. In infancy, affected children may also manifest hypoglycemia, prolonged jaundice with or without giant cell hepatitis, and microphallus in males. The estimated incidence of GHD ranges from 1:4000 to 1:10,000. Causes of GHD can be divided into two main categories: congenital and acquired. Congenital causes can be further subdivided into genetic defects ${ }^{18}$ or anatomical abnormalities (eg, hypothalamic-pituitary stalk transection, optic nerve hypoplasia, and cranial anomalies including holoprosencephaly). ${ }^{19}$ Acquired etiologies of GHD include suprasellar tumors (most commonly, craniopharyngioma), inflammatory processes, infections of the central nervous system, head trauma, ${ }^{20}$ post-surgical, post-radiation, ${ }^{21,22}$ and psychosocial deprivation. ${ }^{23}$ Although there are many known causes of GHD, most cases appear to have an idiopathic basis. Clinically it is important to rule out all other causes of GHD before referring to the etiology of the condition as idiopathic. GHD is most often a secondary phenomenon resulting from a hypothalamic abnormality (ie, low concentrations of GHRH or an inability of GHRH to reach the pituitary) or, less frequently, from a primary disorder of the pituitary gland leading to reduced secretion of GH. GH secretion from the pituitary gland is dependent on the sleep-wake cycle and, therefore, measurement of random serum levels of GH is not clinically useful. Thus, if the diagnosis of GHD is suspected based on poor height velocity, typically the serum concentrations of the $\mathrm{GH}$ surrogates, IGF-1 and IGFBP-3, are measured to screen for GHD. ${ }^{5,24}$ If these levels are found to be low (especially IGF-1), then a GH stimulation test is commonly performed. In most countries, diagnostic criteria for GHD are based on a combination of auxological data and peak GH responses to two GH provocative tests. Criteria for starting treatment are listed in Table $2 .{ }^{25}$

Over the years, multiple medications, capitalizing on either the known pharmacological regulation of endogenous GH secretion or on the physiology of glucose counterregulation in response to hypoglycemia, have been used to provoke GH secretion, including $l$-dopa, insulin, glucagon, clonidine, arginine, and GHRH (no longer available). ${ }^{26}$ Each has possible side effects and reasons for use. The first of these was the insulin tolerance test (ITT) that stimulated GH by inducing hypoglycemia. The advantage of the ITT is that it allows for simultaneous assessment of the ACTH-cortisol axis which should also respond to hypoglycemia, but the risk of severe hypoglycemia during the test is significant. ${ }^{27}$ Many pediatric endocrinologists do not use ITT for this reason. The glucagon stimulation test increases GH secretion by causing an initial rise in the plasma glucose level to $\sim 150 \mathrm{mg} / \mathrm{dL}$, which, in turn, simulates the body to produce insulin to decrease the plasma glucose back to normal, with a frequent nadir of $\sim 60 \mathrm{mg} / \mathrm{dL}$. This physiologically controlled reduction in plasma glucose concentration from slightly above normal to low normal will stimulate GH secretion in non-GH-deficient individuals. There is still a risk of mild hypoglycemia, but severe episodes are far less frequent than occur with the ITT. Clonidine stimulates GH secretion by mimicking the normal $\alpha$-adrenergic regulation of $\mathrm{GH}$ release from the pituitary, but has the risk of inducing hypotension. Since there are risks to performing all of these tests, they should always be performed under the direct supervision of a pediatric endocrinologist and trained nursing staff. An abnormal response to stimulation testing to all agents (except GHRH) is defined arbitrarily as a peak GH level $<10 \mathrm{ng} / \mathrm{mL}$. This definition is controversial because many patients ( $75 \%)$ with apparent idiopathic isolated GHD diagnosed in childhood will have normal GH responses when retested off GH treatment as adolescents during the transition period or as adults. ${ }^{28}$ Due to the limitations of the stimulation testing, two failed GH stimulation tests are often required to make a diagnosis of GHD. This is part of the diagnostic criteria for GHD in many countries, as well as a requirement of insurance companies prior to granting authorization for GH treatment.

\section{Treatment of GHD}

Diagnosis in GHD is based on both clinical and biochemical parameters as described above. Historically, GH preparations were injected intramuscularly to allow complete absorption while limiting antibody formation. However, once it was shown that subcutaneous (SC) injections were equally 
Table 2 Criteria for initiation of growth hormone (GH) treatment in children with $\mathrm{GH}$ deficiency ${ }^{25}$

\begin{tabular}{|c|c|c|c|c|c|}
\hline \multirow[t]{2}{*}{ Country } & \multirow[t]{2}{*}{ Origin of guidelines } & \multicolumn{4}{|l|}{ Criteria } \\
\hline & & Height & Bone age & Growth velocity & Peak GH in provocative test \\
\hline Australia & $\begin{array}{l}\text { Australia Pediatric } \\
\text { Endocrine Group }\end{array}$ & $\begin{array}{l}<\text { Ist } \\
\text { percentile, Ist to } \\
\text { IOth percentile }\end{array}$ & $\begin{array}{l}\text { Boys }<15.5 \mathrm{yr} \\
\text { Girls }<13.5 \mathrm{yr}\end{array}$ & $\begin{array}{l}<25 \text { th percentile for } \\
\text { bone age }\end{array}$ & $<10 \mathrm{mU} / \mathrm{L}$ on 2 tests \\
\hline Canada & $\begin{array}{l}\text { Canadian Advisory } \\
\text { Group }\end{array}$ & $<3$ rd percentile & $<-2 \mathrm{SD}$ & $\begin{array}{l}<3 r d \text { percentile for } \\
\text { bone age }\end{array}$ & $<8 \mathrm{ng} / \mathrm{mL}$ on 2 tests \\
\hline France & Health Authority & $<-2$ SD & & $<-\mathrm{ISD}$ or $<4 \mathrm{~cm} / \mathrm{yr}$ & $<10 \mathrm{ng} / \mathrm{mL}$ on 2 tests \\
\hline Germany & $\begin{array}{l}\text { Working Group } \\
\text { of Pediatric } \\
\text { Endocrinologists }\end{array}$ & short stature & delayed & $\begin{array}{l}<25 \text { th percentile for } \\
\text { bone age }\end{array}$ & $\begin{array}{l}<10 \mathrm{ng} / \mathrm{mL} \text { on } 2 \text { tests, } \\
\text { or }<10 \mathrm{ng} / \mathrm{mL} \text { on I test } \\
\text { with low IGF-I and IGFBP-3 }\end{array}$ \\
\hline Israel & $\begin{array}{l}\text { National GH } \\
\text { Committee }\end{array}$ & & $\begin{array}{l}\text { Boys }<15 \mathrm{yr} \\
\text { Girls }<13 \mathrm{yr}\end{array}$ & $<1.5 \mathrm{SD}$ for $>6 \mathrm{mo}$ & $<8 \mathrm{ng} / \mathrm{mL}$ on 2 tests \\
\hline Japan & $\begin{array}{l}\text { Study Group } \\
\text { of Hypothalamic } \\
\text { Pituitary Disease } \\
\text { of Ministry of } \\
\text { Health and Welfare }\end{array}$ & & $\begin{array}{l}\text { Boys }<16 \mathrm{yr} \\
\text { Girls }<14 \mathrm{yr}\end{array}$ & $\begin{array}{l}\leq-1.5 \text { growth velocity } \\
\text { SD for chronological age } \\
\text { during preceding } 2 \mathrm{yr}\end{array}$ & $<10 \mathrm{ng} / \mathrm{mL}$ on 2 tests \\
\hline Netherlands & GH Advisory Group & & delayed & & $<10 \mathrm{ng} / \mathrm{mL}$ on 2 tests \\
\hline Spain & GH Advisory Group & & & & $<10 \mathrm{ng} / \mathrm{mL}$ on 2 tests \\
\hline Sweden & GH Advisory Group & & & & $<32 \mathrm{mU} / \mathrm{L}$ polyclonal antibody \\
\hline Taiwan & $\begin{array}{l}\text { Society of Pediatric } \\
\text { Endocrinology }\end{array}$ & organic & $\begin{array}{l}\text { Boys }<16 \mathrm{yr} \\
\text { Girls }<14 \mathrm{yr}\end{array}$ & $<4 \mathrm{~cm} / \mathrm{yr}$ & $<10 \mathrm{ng} / \mathrm{mL}$ on 2 tests \\
\hline United States & $\begin{array}{l}\text { Lawson Wilkins } \\
\text { Pediatric Endocrine } \\
\text { Society }{ }^{77}\end{array}$ & $\begin{array}{l}<-2.25 \text { SD for } \\
\text { age or }<2 \text { SD } \\
\text { below mid- } \\
\text { parental height }\end{array}$ & $\begin{array}{l}<2 \text { SD below } \\
\text { mean age }\end{array}$ & $\begin{array}{l}<25 \text { th percentile for } \\
\text { bone age }\end{array}$ & \\
\hline
\end{tabular}

Abbreviations: IGF, insulin-like growth factor; SD, standard deviation.

effective, less painful, and without side effects, ${ }^{29}$ this became the preferred route of administration. The recommended frequency of GH injections has also changed over the years. Originally, pituitary GH was given 2 days per week, but then it was discovered that dividing the weekly dose into 3 injections yielded better growth rates..$^{30}$ It was ultimately discovered that daily injections led to even better growth rates $^{31}$ which has been confirmed by many studies. ${ }^{32-34}$ Serum levels of GH reach a supraphysiological maximum 2 to 6 hours after a SC injection and then fall by about 12 hours. ${ }^{35}$ Injections in the evening have been shown to result in a more physiological pattern of glucose and protein metabolites than if GH is given in the morning. ${ }^{36}$ Therefore, rhGH is currently used as a once-daily SC injection, typically given late in the evening in an attempt to mimic the normal sleep-entrained (nychtemeral) secretory pattern of endogenous GH. ${ }^{35}$

The physiological prepubertal production rate of $\mathrm{GH}$ is $0.02 \mathrm{mg} / \mathrm{kg} /$ day $(0.06 \mathrm{IU} / \mathrm{kg} /$ day $)$ which increases two to four times during puberty. The goal of treatment is to mimic these levels while minimizing side effects. There is a wide range of recommended dosing of GH internationally for the treatment of GHD. GH dose ranges between 0.5 to $0.7 \mathrm{IU} / \mathrm{kg} /$ week ( 0.17 to $0.23 \mathrm{mg} / \mathrm{kg} /$ week) in most countries. ${ }^{25}$ The highest doses are used in the US and range from 0.17 to $0.35 \mathrm{mg} / \mathrm{kg} /$ week, while the smallest doses are used in Japan $(0.5 \mathrm{IU} / \mathrm{kg} /$ week $) .{ }^{25}$ Data from a study by Tanaka using an international survey showed a range of initial GH treatment doses by country (Table 3 ).

Table 3 Growth hormone $(\mathrm{GH})$ treatment doses used in $\mathrm{GH}$ deficiency ${ }^{25}$

\begin{tabular}{ll}
\hline Country & Dosage of GH used \\
\hline Australia & $0.5-0.7 \mathrm{IU} / \mathrm{kg} / \mathrm{wk}\left(\mathrm{I} 4-22 \mathrm{IU} / \mathrm{m}^{2} / \mathrm{wk}\right)$ \\
Canada & $0.18-0.24 \mathrm{mg} / \mathrm{kg} / \mathrm{wk}(0.5-0.72 \mathrm{IU} / \mathrm{kg} / \mathrm{wk})$ \\
France & $0.6-0.9 \mathrm{IU} / \mathrm{kg} / \mathrm{wk}$ \\
Germany & $0.5 \mathrm{IU} / \mathrm{kg} \mathrm{wk}$, can be increased based on response \\
Israel & no limitation \\
Japan & $0.5 \mathrm{IU} / \mathrm{kg} \mathrm{wk}$ \\
Netherlands & $\mathrm{I} 4 \mathrm{U} / \mathrm{m}^{2} / \mathrm{wk}(0.5 \mathrm{IU} / \mathrm{kg} / \mathrm{wk})$, can be \\
& increased based on response \\
Spain & prepubertal $0.5 \mathrm{IU} / \mathrm{kg} / \mathrm{wk}$, puberty \\
& $0.5-0.6 \mathrm{IU} / \mathrm{kg} / \mathrm{wk}$ \\
Sweden & $0.1 \mathrm{U} / \mathrm{kg} / \mathrm{day}(0.7 \mathrm{IU} / \mathrm{kg} / \mathrm{wk})$ \\
Taiwan & $0.7 \mathrm{IU} / \mathrm{kg} / \mathrm{wk}$ \\
United Kingdom & $\mathrm{I} 4-20 \mathrm{IU} / \mathrm{m}^{2} / \mathrm{wk}, 0.5-0.7 \mathrm{IU} / \mathrm{kg} / \mathrm{wk}$ \\
United States & $0.17-0.35 \mathrm{mg} / \mathrm{kg} / \mathrm{wk}(0.525-1.05 \mathrm{IU} / \mathrm{kg} / \mathrm{wk})$ \\
\hline
\end{tabular}


Because of higher secretion of both GH and IGF-1 during normal puberty, the concept of higher replacement doses during puberty has surfaced. Some studies suggest that patients with GHD may achieve greater pubertal growth if treated with higher doses than are typically recommended for prepubertal children to mimic normal pubertal physiology. ${ }^{37-39}$ The results of these small-scale studies were sufficient to engender FDA approval for use of higher doses of GH during puberty in children with GHD (up to $0.7 \mathrm{mg} / \mathrm{kg} /$ week). Monitoring with serum IGF-1 levels specific for age, gender, and Tanner stage must be used to determine the safe and optimal GH dose in puberty. ${ }^{40}$ Currently, many endocrinologists continue treatment through puberty with close monitoring of height velocity, bone age, serum IGF-1 levels, and pubertal progression to ensure the maximal effect of treatment. In most countries, GH therapy is continued until height velocity decreases to $<2.5 \mathrm{~cm} /$ year and/or until the bone age is advanced to between 13 to 15 years for girls and 15.5 to 16 years for boys. ${ }^{25}$ It is now recommended that most patients with childhood-onset GHD be retested for GHD (except perhaps those with prior clear-cut, permanent GH deficiency, ie, those with multiple pituitary hormone deficiencies and/or an abnormal head MRI) after they have reached final height. Newer data suggest that patients with idiopathic isolated GHD should be retested when they start puberty to determine if they are still GH-deficient. If they pass the repeat GH stimulation testing at the beginning of puberty, then they may be able to reach final adult height even if GH treatment is discontinued. ${ }^{41}$

The transition period between adolescence and adulthood is a unique time to reassess the need for GH treatment. In the past, use of GH in children with GHD was continued until epiphyseal fusion occurred; however, there are newer data to suggest that GH has important benefits on bone mineralization, lean body mass, ${ }^{42-44}$ and cardiac risk factors, ie, abnormal lipid profile and excess visceral adiposity. ${ }^{45,46}$ Based on these metabolic benefits, it is suggested that adults may also benefit from GH treatment. For adults with persistent GHD, the effective dose is one-sixth to one-third less than that needed for growing children and adolescents. In order to establish which adults may benefit from continued GH therapy, it is important to determine who is most likely to have persistent GHD. Over $90 \%$ of those patients with multiple pituitary hormone deficiencies and/or clear-cut evidence of organic pituitary disease will have persistent GHD as adults. On the contrary, $67 \%$ up to $75 \%$ patients with idiopathic isolated GHD in childhood will pass repeat GH testing during the transition phase..$^{28,47}$ The exact reason for the discrepancy is uncertain, but may result from variations in testing protocols, the lack of reproducibility of GH provocative testing, variation in GH assay methods, failure to use sex-steroid priming, and the effects of nutrition. ${ }^{48}$ Thus, it is recommended that most patients with isolated GHD be retested, while those with well-delineated organic causes need not be.

\section{Efficacy of GH treatment in GHD}

As stated above, the major goal of GH treatment is to provide the short child with improvement in height velocity in order to attain a final height within the range that is expected for his or her family and, if possible, within the normal range of the general population. We will first discuss the efficacy of treatment as it pertains to GHD. Later we will review the safety of use of rhGH in children, as it is imperative to understand and minimize the risk of any potential undesirable effects.

Multiple studies have assessed the efficacy of rhGH use in children with GHD. Evaluation of patients with GHD shows that multiple factors affect final height: number of injections per week, duration of treatment, age at diagnosis, and, most of all, genetic height potential. The data from the Kabi International Growth Study (KIGS) show that children with GHD can attain improvement in final height with GH treatment increasing +1.6 standard deviation (SD) from baseline and falling within range for family height genetics. ${ }^{49}$ The Swedish analysis of KIGS data showed that subjects with severe GHD (defined as peak $\mathrm{GH}<3.3 \mathrm{ng} / \mathrm{mL}$ ) were shorter than those with partial GHD, even when corrected for mid-parental height, but there was no significant difference between final height in each group. ${ }^{50}$ Data from the National Cooperative Growth Study (NCGS), in which approximately 20,000 children receiving rhGH have been tracked, show that $40 \%$ had idiopathic GHD, while $13.8 \%$ had organic GHD. For subjects who were treated for 7 consecutive years, the mean height SD score increased by $2.5 \mathrm{SD}$ in isolated GHD and by $2.0 \mathrm{SD}$ in organic GHD. ${ }^{51}$ To help determine the optimum GH treatment strategy for children with GHD (and TS), mathematical models have been developed based on clinical data from a large number of subjects. These prediction models are based on known clinical data, including birth status, genetic potential, laboratory data, and GH treatment schedule. The model explains about $61 \%$ of the variability in the growth response to GH. It was noted that a better response is seen in those subjects with the following features: lower peak GH level, younger age at the onset of treatment, larger gap between the subject's height and mid-parental target, higher GH dose, and 
higher body weight and/or birth weight. ${ }^{51,52}$ Further model analysis is being developed to optimize GH treatment in children with GHD.

\section{Turner syndrome Background}

TS is one of the most common causes of short stature in females. TS has an incidence of 1 in 2000 to 1 in 2500 live female births. ${ }^{53}$ It is a sporadic genetic disorder caused by a complete (monosomy) or partial lack of one X chromosome. ${ }^{16}$ Affected females typically present in one of five ways: 1) prenatally with a diagnostic chromosome analysis on amniocentesis (assessed for unrelated reasons, eg, advanced maternal age); 2) at birth, with lymphedema of the hands and feet and other dysmorphic features (eg, webbed neck, with or without associated cardiac abnormalities; 3) during the pre-pubertal age range with short stature and subnormal height velocity with or without subtle dysmorphic features; 4) in adolescence with absent breast development and/or primary amenorrhea; or 5) in adulthood during evaluation for infertility.

Although the primary abnormalities in this disorder are short stature/poor growth velocity in nearly $100 \%$ and primary ovarian failure in $\sim 85 \%$ of girls with TS, other stigmata may be present at varying (but fairly low) frequencies, including webbed neck, low-set pinnae, low posterior hair line, shield-shaped chest, widely-spaced nipples, and increased carrying angles (cubitus valgus). Many girls with TS have left-sided cardiac defects, such as marked tortuosity or ectasia of aortic arch, isolated non-stenotic bicuspid aortic valve, coarctation of the aorta, and hypoplastic left heart syndrome along with non-functional renal abnormalities, including horseshoe-shaped kidneys and duplicated collecting systems.

Growth failure is the most common feature of TS. The growth pattern of girls with TS can be divided into four phases as described by Ranke $\left.{ }^{17}: 1\right)$ intrauterine growth is slightly retarded; 2) normal growth occurs up to a bone age of about 3 years, with a tendency to compensate for the loss in growth during intrauterine life; 3) stunting of growth is progressive and severe during the subsequent childhood years; and 4) the growth phase is prolonged after a bone age of about 10 years, when puberty normally starts and estrogen production normally increases, but, despite this lack of endogenous estrogen-induced epiphyseal fusion in most cases, total height gain is nonetheless markedly reduced. Similarly, Davenport et al described growth in girls with TS showing that mean height SD score fell from -0.5 at birth to -1.5 at age 1 year and to -1.8 at age 1.5 years. Growth curves from this study revealed that growth failure was due to: (a) mild growth retardation in utero, (b) slow growth during infancy, (c) delayed onset of the childhood component of growth, and (d) slow growth during childhood. ${ }^{54}$ Untreated, the average height of women with TS is $143 \mathrm{~cm}$ (4 ft 8 in) which is approximately $20 \mathrm{~cm}$ ( $8 \mathrm{in})$ below the average height of women in the US. ${ }^{55}$

\section{Etiology of short stature}

The etiology of short stature and skeletal abnormalities in TS results in part from haploinsufficiency of the short stature homeobox-containing (SHOX) gene located in the pseudo-autosomal region of the X-chromosome. ${ }^{56}$ SHOX deficiency was identified in girls with TS as well as a small subset $(\sim 1 \%$ to $2 \%)$ of children with "idiopathic" short stature. ${ }^{56}$ The SHOX gene is an important controller of bone growth that regulates chondrocyte differentiation and maturation. ${ }^{57}$ It is now thought that SHOX haploinsufficiency can result not only in short stature, but may play a role in the other skeletal features associated with TS, including cubitus valgus, short metacarpals, Madelung deformity, high-arched palate, and short neck. ${ }^{58}$

In order to treat a child with TS with $\mathrm{GH}$, the diagnosis of TS must be confirmed, but GH stimulation testing is ordinarily not necessary. GH secretion in TS has been studied to determine if an abnormality of secretion affects height. An Italian study by Cavallo et $\mathrm{al}^{59}$ showed that impairment of $\mathrm{GH}$ secretion is frequent in girls with TS, especially if they are obese (a finding not unique to the TS population), and that impairment of GH secretion is not related to karyotype or spontaneous thelarche and/or pubarche or height. The authors concluded that although GH secretion (both GH reserve and mean spontaneous nocturnal secretion) is abnormal, it did not influence height in TS patients. Thus, stimulation testing in patients with TS is unnecessary. ${ }^{59}$ rhGH therapy has been approved in the US for use in children with TS since 1996. Efficacy of GH in TS will be discussed later, but it is interesting to note that patients with SHOX deficiency, not associated with TS, also respond to GH. Final height in isolated SHOX deficiency is similar to that in patients with TS. $^{60}$ Isolated SHOX deficiency was also approved by the FDA as an indication for GH treatment in 2006.

\section{Treatment of TS}

The FDA-approved dose of rhGH for treatment of girls with TS in the US is from $0.36 \mathrm{mg} / \mathrm{kg} /$ week up to $0.46 \mathrm{mg} / \mathrm{kg} /$ week. Unlike for patients with GHD, there is no 
approved step-up in rhGH dose during the pubertal age by any governmental regulatory agency. In Japan, low-dose GH treatment at $0.175 \mathrm{mg} / \mathrm{kg} /$ week was used previously, but, as of December 1999, a higher dose of $0.35 \mathrm{mg} / \mathrm{kg} /$ week was approved. ${ }^{51,61}$ A prospective study of GH dosing in TS by Van Pareren et al examined 3 groups over a 4-year course of GH treatment. Group A was given $\mathrm{GH}$ at a dose of $4 \mathrm{IU} / \mathrm{m}^{2} /$ day $(\sim 0.045 \mathrm{mg} / \mathrm{kg} / \mathrm{day})$ for all 4 years, group B had an increase in dosage from $4 \mathrm{IU} / \mathrm{m}^{2} /$ day to $6 \mathrm{IU} / \mathrm{m}^{2} /$ day $(\sim 0.068 \mathrm{mg} / \mathrm{kg} /$ day $)$ in the second year, and group $\mathrm{C}$ had the same doses as in group B in years 1 and 2 , and then was increased further in year 3 to $8 \mathrm{IU} / \mathrm{m}^{2} /$ day $(\sim 0.09 \mathrm{mg} / \mathrm{kg} /$ day $)$. Results showed that Group A had the shortest final height of $157.6 \pm 6.5 \mathrm{~cm}$, while groups B $(162.9 \pm 6.1)$ and $C(163.6 \pm 6.0)$ showed a significant increase in height compared to Group $\mathrm{A}$ $(P<0.001)$. Groups B and $\mathrm{C}$ were not statistically different from one another. ${ }^{62}$ These results showed that higher doses of GH in girls with TS improve final height.

Estrogen is critical for bone growth and epiphyseal maturation in both male and females, especially during puberty. The delicate balance between GH and estrogen becomes critical in patients with TS, most of whom have gonadal failure and require estrogen therapy to induce pubertal changes. While historically estrogen replacement has been intentionally delayed in girls with TS to maximize height through later epiphyseal closure (including those girls receiving $\mathrm{GH}$ ), the current trend is to begin estrogen replacement at a younger age, more akin to that when gonadarche occurs in normal girls. Although improvement in height outcome is still desired with this approach, it may also allow for normal bone mineral accretion and better psychosocial adaptation with normally timed puberty. ${ }^{63}$ In the study by Quigley et al ${ }^{64}$ patients with TS were treated with $\mathrm{GH}$ (at either 0.27 or $0.36 \mathrm{mg} / \mathrm{kg} /$ week) in combination with either pacebo or low-dose estrogen $(100 \mathrm{ng} / \mathrm{kg} /$ day of ethinyl estradiol) to determine change in SD scores from baseline to near-final height. The two groups receiving higher $\mathrm{GH}$ doses with and without estrogen showed final heights of $149.1 \pm 6.0 \mathrm{~cm}$ and $150.4 \pm 6.0 \mathrm{~cm}$, respectively. The near-final heights of those treated with lower GH doses were $145.1 \pm 5.4 \mathrm{~cm}$ and $149.9 \pm 6.0 \mathrm{~cm}$, respectively. The change in SD scores between subjects with GH and estrogen treatment and those with $\mathrm{GH}$ and placebo was $0.7 \pm 0.1$ vs $0.9 \pm 0.1(P=0.11)$. The difference in standard deviation score (SDS) was not statistically significant. It is unclear from this study if estrogen treatment improves, compromises, or has no effect on final height. ${ }^{64}$ The treatment paradigm shift toward earlier introduction of estrogen, has been facilitated by the availability of transdermal estrogen patches, which can be cut to provide very small doses of estrogen. The delicate balance of estrogen replacement for pubertal development and GH treatment to optimize height must be individualized for each patient by the pediatric endocrinologist.

\section{Efficacy of GH treatment in TS}

Patients with TS benefit from GH therapy with improvement in final height. The degree of benefit depends on the age at which therapy begins, dose given, duration of treatment, mid-parental target height, and when concurrent therapy with estrogen is used to induce puberty. The Ranke prediction model for TS incorporates data from Kabi International Growth Study (KIGS), including the above factors, into a mathematical model to help determine the association between the clinical parameters and near-final height. ${ }^{51,52,65}$ This analysis showed that younger age at onset of treatment, taller parents (higher mid-parental target height), and later onset of puberty were associated with taller near-final height compared to projected, ie, from $146.1 \mathrm{~cm}$ to $151.0 \mathrm{~cm} .{ }^{65}$ The Toddler Turner study prospectively compared the short-term height outcomes of girls started on rhGH between the ages of 9 months and 4 years to see if there were a significant difference in height compared to patients with TS of the same age randomized not to receive GH treatment. Those given $\mathrm{rhGH}$ at $0.35 \mathrm{mg} / \mathrm{k} /$ week had statistically significant improvement in mean height SDS increasing by $1.1 \mathrm{SDS}$ (from $-1.4 \pm 1.0$ to $-0.3 \pm 1.1$ ), while those without treatment had a decrease in height SDS of 0.5 SDS from $-1.8 \pm 1.1$ to $-2.2 \pm 1.2,(P<0.0001) .{ }^{66}$ Whether these preliminary observations will translate into better adult height than typically has been achieved in girls with TS (with a mean age of start of treatment in clinical practice still not until 9 years in the US) is being investigated in the 10-year follow-up study known as the Turner Tween Study. Final height analysis done by Morin et al in a cohort of 25 girls who were followed for median 3.8 years (2.1 to 10.3 years) showed height gain in the GH treatment group that was $11.2 \pm 3.7 \mathrm{~cm}$ over that originally predicted, ie, 5 feet vs $4 \mathrm{ft} 8 \mathrm{in}$. Of the 25 girls, only one $(4 \%)$ was projected to meet the third percentile before GH treatment, compared to follow-up after treatment when 14 of 25 girls $(56 \%)$ had final heights on the third percentile. ${ }^{67}$ A randomized, controlled trial of GH treatment of 154 girls with TS was performed in Canada. At study entry, girls were 7 to 13 years old. They were randomly assigned to be given $\mathrm{GH}$ as six $\mathrm{SC}$ injections/week at a total dose of $0.3 \mathrm{mg} / \mathrm{kg} /$ week or to a control group that received no treatment. Mean heights at follow-up for treated subjects 
were $147.5 \pm 6.1 \mathrm{~cm}$ vs $141 \pm 5.4 \mathrm{~cm}$ for controls $(P<0.001)$. Mean height gain due to GH was estimated to be $7.2 \mathrm{~cm}$ (confidence interval, 6.0 to 8.4 ) at study completion. ${ }^{68}$ The final height outcomes in the Dutch study for treatment in TS were much more favorable. This study included younger children (ages 2 to 11 years) at baseline and was designed to study dose response. Girls were randomized into one of three groups: a) $4 \mathrm{IU} / \mathrm{m}^{2}$; b) $4 \mathrm{IU} / \mathrm{m}^{2}$ in the first year followed by $6 \mathrm{IU} / \mathrm{m}^{2}$ thereafter; and c) $4 \mathrm{IU} / \mathrm{m}^{2}$ in the first year followed by $6 \mathrm{IU} / \mathrm{m}^{2}$ in the second year, and $8 \mathrm{IU} / \mathrm{m}^{2}$ for the remainder of the study. Of 25 girls who completed the study, the mean final heights were $159.1 \mathrm{~cm}, 161.8 \mathrm{~cm}$, and $162.7 \mathrm{~cm}$ in groups $\mathrm{a}, \mathrm{b}$, and c, respectively. The final height gain in each group was $12.5 \mathrm{~cm}, 14.6 \mathrm{~cm}$, and $16.0 \mathrm{~cm}$, respectively. These better results may be due to an overall higher dosing paradigm of GH employed, younger age at the beginning of treatment, and/or better genetic potential in the Netherlands. ${ }^{69}$ It is clear that GH therapy is beneficial to the height of girls with TS and, thus, guidelines for the treatment of patients with TS almost universally include treatment with GH.

\section{Safety and side effects of GH treatment}

Multiple studies have assessed the safety of rhGH use in children with GHD and TS. Overall, GH therapy is relatively safe with the most common side effects being pain or bruising at the injection site, mild headache, and muscle or joint pain. Rare, but serious, side effects can occur including benign intracranial hypertension (pseudotumor cerebri), type 2 diabetes mellitus (T2DM), and slipped capital femoral epiphysis (SCFE).

The reported incidence of benign intracranial hypertension is $\sim 27.7$ per 100,000 treatment-years in children treated with $\mathrm{GH} .{ }^{70}$ The incidence of benign intracranial hypertension in patients with idiopathic GHD is much less than in those with either congenital GHD or TS. Benign intracranial hypertension typically presents with signs of increased intracranial pressure including severe headache, papilledema, visual changes, nausea, and/or vomiting. This generally occurs within the first 8 weeks of treatment. Therapeutic lumbar puncture can be used to treat this condition which usually resolves with cessation of GH therapy. Often GH treatment can be resumed at a much lower dose with gradual escalation without recurrence of benign intracranial hypertension.

GH induces insulin resistance which increases the risk of developing T2DM during GH treatment. There is also a risk of worsening glycemic control in patients with pre-existing diabetes, either type 1 or type 2 . Since glucocorticoids also reduce insulin sensitivity, it is important to carefully monitor patients treated with both $\mathrm{GH}$ and glucocorticoids. In the NCGS, the subjects treated with both GH and glucocorticoids had a slight increase in mean hemoglobin A1c levels, but glucose and insulin levels were not statistically different between the two groups. ${ }^{71} \mathrm{GH}$-induced IGF-1 secretion also inhibits the expression of $11 \beta$-hydroxysteroid dehydrogenase (11ß-HSD1), which catalyzes the conversion of cortisone to cortisol. Therefore, GH therapy may decrease the amount of cortisol production. Replacement with GH should be done cautiously in patients subject to adrenal crisis who may also have ACTH deficiency. ${ }^{72}$ Similarly, in patients at risk for multiple pituitary hormone deficiencies, it has been shown that GH treatment can unmask hypothyroidism in a subset of patients. ${ }^{73}$

A large retrospective study done by Cutfield et al found that $0.36 \%$ of children treated with GH ( 85 of 23,333$)$ had abnormal glucose metabolism, with 11 having type 1 diabetes (T1DM), 18 T2DM, and 14 impaired glucose tolerance. The incidence of T1DM in those treated with GH was not different than the expected number in the general population. However, the incidence of T2DM was six-fold higher than reported in those not on GH therapy. ${ }^{74}$ It is thought that genetically predisposed individuals are more prone to this effect. If T2DM develops, it usually will resolve (at least temporarily) with discontinuation of GH therapy.

According to the KIGS analysis, the total incidence of SCFE is 73.4 per 100,000 treatment-years of children treated with $\mathrm{GH} .{ }^{70} \mathrm{SCFE}$ presents as lower extremity pain in the hip or referred to the knee, and often with an inability to walk. Plain x-ray films of the hips can confirm the diagnosis. If SCFE is present, surgical pinning is needed to stabilize the hip joint. This is more likely to occur in overweight children and is also typically seen early, within the first 8 weeks of initiation of treatment.

To assess the long-term safety of GH therapy, data entered into the NCGS between 1985-2006 were analyzed. In this study, 54,996 children treated with rhGH were followed and the overall incidence of targeted events of intracranial hypertension, T2DM, and SCFE, along with scoliosis, pancreatitis, and adrenal insufficiency was quite low $(<1 \%)$. The data were separated based on diagnosis and included 23,393 subjects with idiopathic GHD and 8,351 with organic GHD, as well as 5127 with TS. The malignancy rate in IGHD was zero, but was $0.1 \%$ in both the OGHD and TS groups. The overall incidence of de novo malignancies, including leukemia and intracranial and extracranial tumors, in children treated with GH, was not increased. 
Second neoplasms, in patients with previous cancer and irradiation, occurred at an increased rate compared to the amount expected for a population without GH treatment and with similar risk. ${ }^{75}$ No unusual safety signals were evident in girls with TS treated with rhGH.

\section{Patient preferences}

There are many available forms of somatotropin in the US. All the current products contain the same molecule and have presumed comparable efficacy. However, the products differ in reconstitution methods, concentration of somatotropin, delivery device, storage requirements, preservative content, and time to expiration. Thus, patients/families may prefer one brand over another due to the ease of use with a certain device or convenience of longer storage. Research has been done on patient preferences and found that the choice of GH delivery device is influenced by whether or not a device causes bruising, has an auto-injector, and/or causes pain. Parents also preferred a light-weight device that is easy to hold, has silent delivery, and uses a ready-mixed drug. ${ }^{76}$ Awareness of these preferences is important, but the reality in choice of brand of GH treatment is that insurance companies often dictate which brand or device can be prescribed.

\section{Conclusions}

Treatment with GH is both efficacious and safe in patients with GHD, TS, and all other conditions for which it is approved. Patients with GHD benefit from treatment whether or not they have an underlying organic or idiopathic etiology. Patients with TS gain maximal benefit if the treatment is started early in childhood and continued until near-final height is attained. Multiple brands are available as well and all have similar efficacy, but physician and patient preferences, and insurance coverage influence the ultimate choice of GH. It is important to determine how the cost of treatment may be balanced with the effect of therapy. The marketplace for $\mathrm{GH}$ is quite competitive and we need to determine how treatment can be administered in a cost-effective manner that is beneficial to our patients.

\section{Disclosures}

Mitchell E Geffner declares the following:

$\begin{array}{ll}\text { Eli Lilly, Inc.: } & \text { Research Contract } \\ \text { EMD-Serono: } & \text { Advisory Board } \\ \text { Endo Pharmaceuticals: } & \text { Advisory Board } \\ \text { Genentech, Inc.: } & \text { Grant Review Board, Research } \\ & \text { Grant, and Research Contract }\end{array}$

Novo Nordisk:

Pfizer, Inc.:

Tercica, Inc.:

Christina Southern Reh has no conflicts of interest to disclose.

\section{References}

1. Grumbach MM, Bin-Abbas BS, Kaplan SL. The growth hormone cascade: progress and long-term results of growth hormone treatment in growth hormone deficiency. Horm Res. 1998;49 Suppl 2:41-57.

2. Baumann GP. Growth hormone isoforms. Growth Horm IGF Res. 2009;19(4):333-340.

3. Cone RD, Cowley MA, Butler AA, Fan W, Marks DL, Low MJ. The arcuate nucleus as a conduit for diverse signals relevant to energy homeostasis. Int $J$ Obes Relat Metab Disord. 2001;25 Suppl 5: S63-S67.

4. Lengyel AM. Novel mechanisms of growth hormone regulation: growth hormone-releasing peptides and ghrelin. Braz J Med Biol Res. 2006;39(8):1003-1011.

5. Cohen P, Rosenfeld RG. Physiologic and clinical relevance of the insulin-like growth factor binding proteins. Curr Opin Pediatr. 1994;6(4):462-467.

6. Melhus $\mathrm{H}$, Ljunghall S. Growth hormone and insulin-like growth factor-I do not activate identical genes in normal human osteoblasts. Biochem Mol Biol Int. 1996;38(2):425-428.

7. Green H, Morikawa M, Nixon T. A dual effector theory of growth-hormone action. Differentiation. 1985;29(3):195-198.

8. Gevers EF, Hannah MJ, Waters MJ, Robinson IC. Regulation of rapid signal transducer and activator of transcription-5 phosphorylation in the resting cells of the growth plate and in the liver by growth hormone and feeding. Endocrinology. 2009;150(8):3627-3636.

9. Eugster EA, Pescovitz OH. New revelations about the role of STATs in stature. N Engl J Med. 2003;349(12):1110-1112.

10. Gertner JM. Growth hormone actions on fat distribution and metabolism. Horm Res. 1992;38 Suppl 2:41-43.

11. Raben MS. Treatment of a pituitary dwarf with human growth hormone. J Clin Endocrinol Metab. 1958;18(8):901-903.

12. Frasier SD. The not-so-good old days: working with pituitary growth hormone in North America, 1956 to 1985. J Pediatr. 1997;131(1 Pt 2):S1-S4.

13. Goeddel DV, Heyneker HL, Hozumi T, et al. Direct expression in Escherichia coli of a DNA sequence coding for human growth hormone. Nature. 1979;281(5732):544-548.

14. Flodh H. Human growth hormone produced with recombinant DNA technology: development and production. Acta Paediatr Scand Suppl. 1986;325:1-9.

15. Massa G, Vanderschueren-Lodeweyckx M, Bouillon R. Five-year follow-up of growth hormone antibodies in growth hormone deficient children treated with recombinant human growth hormone. Clin Endocrinol (Oxf). 1993;38(2):137-142.

16. Franklin SL, Geffner ME. Growth hormone: the expansion of available products and indications. Endocrinol Metab Clin North Am. 2009;38(3):587-611.

17. Ranke MB. New preparations comprising recombinant human growth hormone: deliberations on the issue of biosimilars. Horm Res. 2008; 69(1):22-28.

18. Mullis PE, Deladoey J, Dannies PS. New GH-1 gene mutations: expanding the spectrum of causes of isolated growth hormone deficiency. J Pediatr Endocrinol Metab. 2002;15 Suppl 5:1301-1310.

19. Dubourg C, Bendavid C, Pasquier L, Henry C, Odent S, David V. Holoprosencephaly. Orphanet J Rare Dis. 2007;2:8. 
20. Yamanaka C, Momoi T, Fujisawa I, et al. Acquired growth hormone deficiency due to pituitary stalk transection after head trauma in childhood. Eur J Pediatr. 1993;152(2):99-101.

21. Bocca G, van Beek AP, de Bont ES. [Grow hormone deficiency in children after radiation for a brain tumor. Quickly start with substitution]. Ned Tijdschr Geneeskd. 2009;153(17):792-793.

22. Darzy KH, Shalet SM. Pathophysiology of radiation-induced growth hormone deficiency: efficacy and safety of GH replacement. Growth Horm IGF Res. 2006;16 Suppl A:S30-S40.

23. Mouridsen SE, Nielsen S. Reversible somatotropin deficiency (psychosocial dwarfism) presenting as conduct disorder and growth hormone deficiency. Dev Med Child Neurol. 1990;32(12):1093-1098.

24. Rosenfeld RG, Pham H, Cohen P, et al. Insulin-like growth factor binding proteins and their regulation. Acta Paediatr Suppl. 1994;399:154-158.

25. Tanaka T. Global situation of growth hormone treatment in growth hormone- deficient children. Horm Res. 1999;51 Suppl 3:75-80.

26. Frasier SD. A preview of growth hormone stimulation tests in children. Pediatrics. 1974;53(6):929-937.

27. Shah A, Stanhope R, Matthew D. Hazards of pharmacological tests of growth hormone secretion in childhood. BMJ. 1992; 304(6820): 173-174.

28. Bonfig W, Bechtold S, Bachmann S, et al. Reassessment of the optimal growth hormone cut-off level in insulin tolerance testing for growth hormone secretion in patients with childhood-onset growth hormone deficiency during transition to adulthood. J Pediatr Endocrinol Metab. 2008;21(11):1049-1056.

29. Wilson DM, Baker B, Hintz RL, Rosenfeld RG. Subcutaneous versus intramuscular growth hormone therapy: growth and acute somatomedin response. Pediatrics. 1985;76(3):361-364.

30. Milner RD, Russell-Fraser T, Brook CG, et al. Experience with human growth hormone in Great Britain: the report of the MRC Working Party. Clin Endocrinol (Oxf). 1979;11(1):15-38.

31. Kastrup KW, Christiansen JS, Andersen JK, Orskov H. Increased growth rate following transfer to daily sc administration from three weekly im injections of $\mathrm{hGH}$ in growth hormone deficient children. Acta Endocrinol (Copenh). 1983;104(2):148-152.

32. Jorgensen JO, Moller N, Lauritzen T, Alberti KG, Orskov H, Christiansen JS. Evening versus morning injections of growth hormone $(\mathrm{GH})$ in $\mathrm{GH}$-deficient patients: effects on 24-hour patterns of circulating hormones and metabolites. J Clin Endocrinol Metab. 1990; 70:207-214.

33. bertsson-Wikland K, Westphal O, Westgren U. Daily subcutaneous administration of human growth hormone in growth hormone deficient children. Acta Paediatr Scand. 1986;75:89-97.

34. MacGillivray MH, Baptista J, Johanson A. Outcome of a four-year randomized study of daily versus three times weekly somatropin treatment in prepubertal naive growth hormone-deficient children. Genentech Study Group. J Clin Endocrinol Metab. 1996;81: 1806-1809.

35. Ranke MB, Schweizer R, Wollmann HA, Schwarze P. Dosing of growth hormone in growth hormone deficiency. Horm Res. 1999;51 Suppl 3:70-74

36. Jorgensen JO, Moller J, Moller N, Lauritzen T, Christiansen JS. Pharmacological aspects of growth hormone replacement therapy: route, frequency and timing of administration. Horm Res.1990;33 Suppl 4:77-82.

37. Codner E, Mericq V, Cassorla F. Optimizing growth hormone therapy during puberty. Horm Res. 1997;48 Suppl 5:16-20.

38. Mauras N, Attie KM, Reiter EO, Saenger P, Baptista J. High dose recombinant human growth hormone $(\mathrm{GH})$ treatment of GH-deficient patients in puberty increases near-final height: a randomized, multicenter trial. Genentech, Inc., Cooperative Study Group. J Clin Endocrinol Metab. 2000;85(10):3653-3660.

39. Saenger P. Dose effects of growth hormone during puberty. Horm Res. 2003;60 Suppl 1:52-57.

40. Park P, Cohen P. The role of insulin-like growth factor I monitoring in growth hormone-treated children. Horm Res. 2004;62 Suppl 1:59-65.
41. Zucchini S, Pirazzoli P, Baronio F, et al. Effect on adult height of pubertal growth hormone retesting and withdrawal of therapy in patients with previously diagnosed growth hormone deficiency. J Clin Endocrinol Metab. 2006;91(11):4271-4276.

42. Saggese G, Baroncelli GI. Bone mineral density and biochemical parameters of bone turnover in children with growth hormone deficiency. Horm Res. 1996;45 Suppl 1:67-68.

43. Underwood LE, Attie KM, Baptista J. Growth hormone (GH) dose-response in young adults with childhood-onset $\mathrm{GH}$ deficiency: a two-year, multicenter, multiple-dose, placebo-controlled study. J Clin Endocrinol Metab. 2003;88(11):5273-5280.

44. Boguszewski CL, Meister LH, Zaninelli DC, Radominski RB. One year of $\mathrm{GH}$ replacement therapy with a fixed low-dose regimen improves body composition, bone mineral density and lipid profile of GH-deficient adults. Eur J Endocrinol. 2005;152(1): $67-75$.

45. Colao A, Di SC, Salerno M, Spinelli L, Orio F, Lombardi G. The cardiovascular risk of GH-deficient adolescents. J Clin Endocrinol Metab. 2002;87(8):3650-3655.

46. Lanes R, Paoli M, Carrillo E, Villaroel O, Palacios A. Cardiovascular risk of young growth-hormone-deficient adolescents. Differences in growth-hormone-treated and untreated patients. Horm Res. 2003;60(6):291-296.

47. Geffner ME. Transition to the adult endocrine clinic: testing pituitary function - what tests and when? Growth Horm IGF Res. 2003;13 Suppl A:S117-S121.

48. Sizonenko PC, Clayton PE, Cohen P, Hintz RL, Tanaka T, Laron Z. Diagnosis and management of growth hormone deficiency in childhood and adolescence. Part 1: diagnosis of growth hormone deficiency. Growth Horm IGF Res. 2001;11(3):137-165.

49. Cutfield W, Lindberg A, Albertsson WK, Chatelain P, Ranke MB, Wilton P. Final height in idiopathic growth hormone deficiency: the KIGS experience. KIGS International Board. Acta Paediatr Suppl. 1999;88(428):72-75.

50. Westphal O, Lindberg A. Final height in Swedish children with idiopathic growth hormone deficiency enrolled in KIGS treated optimally with growth hormone. Acta Paediatr. 2008;97(12):1698-1706.

51. Root AW, Kemp SF, Rundle AC, Dana K, Attie KM. Effect of long-term recombinant growth hormone therapy in children - the National Cooperative Growth Study, USA, 1985-1994. J Pediatr Endocrinol Metab. 1998;11(3):403-412.

52. Geffner ME, Dunger DB. Future directions: growth prediction models. Horm Res. 2007;68 Suppl 5:51-56.

53. Gravholt $\mathrm{CH}$. Epidemiological, endocrine and metabolic features in Turner syndrome. Eur J Endocrinol. 2004;151(6):657-687.

54. Davenport ML, Punyasavatsut N, Gunther D, Savendahl L, Stewart PW. Turner syndrome: a pattern of early growth failure. Acta Paediatr Suppl. 1999;88(433):118-121.

55. Ranke MB, Stubbe P, Majewski F, Bierich JR. Spontaneous growth in Turner's syndrome. Acta Paediatr Scand Suppl. 1988;343:22-30.

56. Rao E, Weiss B, Fukami M, et al. Pseudoautosomal deletions encompassing a novel homeobox gene cause growth failure in idiopathic short stature and Turner syndrome. Nat Genet. 1997;16(1):54-63.

57. Blaschke RJ, Rappold G. The pseudoautosomal regions, SHOX and disease. Curr Opin Genet Dev. 2006;16(3):233-239.

58. Ogata T. SHOX haploinsufficiency and its modifying factors. J Pediatr Endocrinol Metab. 2002;15 Suppl 5:1289-1294.

59. Cavallo L, Gurrado R. Endogenous growth hormone secretion does not correlate with growth in patients with Turner's syndrome. Italian Study Group for Turner Syndrome. J Pediatr Endocrinol Metab. 1999; 12(5):623-627.

60. Blum WF, Cao D, Hesse V, et al. Height gains in response to growth hormone treatment to final height are similar in patients with SHOX deficiency and Turner syndrome. Horm Res. 2009;71(3): 167-172.

61. Ito Y, Fujieda K, Tanaka T, et al. Low-dose growth hormone treatment $(0.175 \mathrm{mg} / \mathrm{kg} /$ week) for short stature in patients with Turner Syndrome: data from KIGS Japan. Endocr J. 2006;53(5):699-703. 
62. Van Pareren YK, de Muinck Keizer-Schrama SM, Stijnen T, et al. Final height in girls with turner syndrome after long-term growth hormone treatment in three dosages and low dose estrogens. J Clin Endocrinol Metab. 2003;88(3):1119-1125.

63. McCarthy K, Bondy CA. Turner syndrome in childhood and adolescence. Expert Rev Endocrinol Metab. 2008;3(6):771-775.

64. Quigley CA, Crowe BJ, Anglin DG, Chipman JJ. Growth hormone and low dose estrogen in Turner syndrome: results of a United States multi-center trial to near-final height. J Clin Endocrinol Metab. 2002;87(5):2033-2041.

65. Ranke MB, Lindberg A, Ferrandez LA, et al. Major determinants of height development in Turner syndrome (TS) patients treated with GH: analysis of 987 patients from KIGS. Pediatr Res. 2007;61(1):105-110.

66. Davenport ML, Crowe BJ, Travers SH, et al. Growth hormone treatment of early growth failure in toddlers with Turner syndrome: a randomized, controlled, multicenter trial. J Clin Endocrinol Metab. 2007;92(9):3406-3416.

67. Morin A, Guimarey LM, Apezteguia M, Santucci ZC. Adult height in Turner Syndrome girls after long-term growth hormone treatment. Medicina (B Aires). 2009;69(4):431-436.

68. Stephure DK. Impact of growth hormone supplementation on adult height in turner syndrome: results of the Canadian randomized controlled trial. J Clin Endocrinol Metab. 2005;90(6):3360-3366.

69. De MKS, Van den BJ, Sas T, Hokken-Koelega A. Final height of growth hormone-treated GH-deficient children and girls with Turner's syndrome: the Dutch experience. The Dutch Advisory Group on Growth Hormone. Horm Res. 1999;51 Suppl 3:127-131.
70. Darendeliler F, Karagiannis G, Wilton P. Headache, idiopathic intracranial hypertension and slipped capital femoral epiphysis during growth hormone treatment: a safety update from the KIGS database. Horm Res. 2007;68 Suppl 5:41-47.

71. Allen DB, Julius JR, Breen TJ, Attie KM. Treatment of glucocorticoid-induced growth suppression with growth hormone. National Cooperative Growth Study. JClin Endocrinol Metab. 1998;83(8): 2824-2829.

72. Agha A, Monson JP. Modulation of glucocorticoid metabolism by the growth hormone - IGF-1 axis. Clin Endocrinol (Oxf). 2007;66(4): $459-465$.

73. Agha A, Walker D, Perry L, et al. Unmasking of central hypothyroidism following growth hormone replacement in adult hypopituitary patients. Clin Endocrinol (Oxf). 2007;66(1):72-77.

74. Cutfield WS, Wilton P, Bennmarker $\mathrm{H}$, et al. Incidence of diabetes mellitus and impaired glucose tolerance in children and adolescents receiving growth-hormone treatment. Lancet. 2000;355(9204): 610-613.

75. Bell J, Parker KL, Swinford RD, Hoffman AR, Maneatis T, Lippe B. Long-term safety of recombinant human growth hormone in children. $J$ Clin Endocrinol Metab. 2010;95(1):167-177.

76. Ahmed SF, Smith WA, Blamires C. Facilitating and understanding the family's choice of injection device for growth hormone therapy by using conjoint analysis. Arch Dis Child. 2008;93(2):110-114.

77. Wilson TA, Rose SR, Cohen P, et al. Update of guidelines for the use of growth hormone in children: the Lawson Wilkins Pediatric Endocrinology Society Drug and Therapeutics Committee. J Pediatr. 2003;143(4):415-421.
Clinical Pharmacology: Advances and Applications

\section{Publish your work in this journal}

Clinical Pharmacology: Advances and Applications is an international, peer-reviewed, open access journal publishing original research, reports, reviews and commentaries on all areas of drug experience in humans. The manuscript management system is completely online and includes a very quick and fair peer-review system, which is all easy to use.

\section{Dovepress}

Visit http://www.dovepress.com/testimonials.php to read real quotes from published authors. 